\title{
Impact of minimum catch size on the population viability of Strombus gigas (Mesogastropoda: Strombidae) in Quintana Roo, Mexico
}

\author{
Joanne R. Peel \& María del Carmen Mandujano \\ Instituto de Ecología, Universidad Nacional Autónoma de México, UNAM, Código postal 70-275, 04510 Coyoacán, \\ D.F., México; jrpeel@gmx.de; mcmandujano@gmail.com; mcmandu@ecologia.unam.mx
}

\author{
Received 10-II-2014. Corrected 05-VII-2014. Accepted 13-VIII-2014.
}

\begin{abstract}
The queen conch Strombus gigas represents one of the most important fishery resources of the Caribbean but heavy fishing pressure has led to the depletion of stocks throughout the region, causing the inclusion of this species into CITES Appendix II and IUCN's Red-List. In Mexico, the queen conch is managed through a minimum fishing size of $200 \mathrm{~mm}$ shell length and a fishing quota which usually represents $50 \%$ of the adult biomass. The objectives of this study were to determine the intrinsic population growth rate of the queen conch population of Xel-Ha, Quintana Roo, Mexico, and to assess the effects of a regulated fishing impact, simulating the extraction of $50 \%$ adult biomass on the population density. We used three different minimum size criteria to demonstrate the effects of minimum catch size on the population density and discuss biological implications. Demographic data was obtained through capture-mark-recapture sampling, collecting all animals encountered during three hours, by three divers, at four different sampling sites of the Xel-Ha inlet. The conch population was sampled each month between 2005 and 2006, and bimonthly between 2006 and 2011, tagging a total of 8292 animals. Shell length and lip thickness were determined for each individual. The average shell length for conch with formed lip in Xel-Ha was $209.39 \pm 14.18 \mathrm{~mm}$ and the median $210 \mathrm{~mm}$. Half of the sampled conch with lip ranged between $200 \mathrm{~mm}$ and $219 \mathrm{~mm}$ shell length. Assuming that the presence of the lip is an indicator for sexual maturity, it can be concluded that many animals may form their lip at greater shell lengths than $200 \mathrm{~mm}$ and ought to be considered immature. Estimation of relative adult abundance and densities varied greatly depending on the criteria employed for adult classification. When using a minimum fishing size of $200 \mathrm{~mm}$ shell length, between $26.2 \%$ and up to $54.8 \%$ of the population qualified as adults, which represented a simulated fishing impact of almost one third of the population. When conch extraction was simulated using a classification criteria based on lip thickness, it had a much smaller impact on the population density. We concluded that the best management strategy for $S$. gigas is a minimum fishing size based on a lip thickness, since it has lower impact on the population density, and given that selective fishing pressure based on size may lead to the appearance of small adult individuals with reduced fecundity. Furthermore, based on the reproductive biology and the results of the simulated fishing, we suggest a minimum lip thickness of $\geq 15 \mathrm{~mm}$, which ensures the protection of reproductive stages, reduces the risk of overfishing, leading to non-viable density reduction. Rev. Biol. Trop. 62 (4): 1343-1352. Epub 2014 December 01.
\end{abstract}

Key words: Fishery management, fishing sustainability, overfishing, population simulation, population viability, sexual maturity.

The Xel-Ha inlet is a highly stratified, enclosed coastal lagoon, which has been used since 1995 as a park for ecotourism and is considered a sanctuary for many species of commercial interest, including the queen conch (Strombus gigas Linnaeus, 1758), with an important population composed of juveniles, subadults, reproductive and old adults (Baqueiro-Cárdenas, \& Aldana-Aranda, 2010), as well as the occurrence of pelagic larvae (Chávez-Villegas, 2011), suggesting that the conch completes its life cycle within the limits of the inlet. In terms of growth and survival, Xel-Ha presents several features of a nursery for $S$. gigas (Peel, 2012).

The $S$. gigas is the largest representative of the six species of Strombidae found in the Western Atlantic. Strombus gigas' most distinctive 
feature is its shell, which may be light brown or beige from the outside, with a well-defined protruding spire, and bright pink, sometimes with a yellow or orange tint in the inside (Abott, 1974). The shell grows fast until reaching its maximum length at around $24-29 \mathrm{~cm}$. At this point the characteristic flared lip starts to form and all subsequent growth manifests as thickening of the lip and shell (Randall, 1964; Alcolado, 1976; Appeldoorn, 1994). S.gigas is dioecious and fertilization is internal. Under natural conditions, the populations in balance maintain a sex ratio of 1:1 (Randall, 1964; Davis, Mitchell, \& Brown, 1984).

The queen conch $S$. gigas represents one of the most important fishery resources of the Caribbean (Appeldoorn, 1994; Thiele, 2001) but heavy fishing pressure (legal and illegal) has led to the depletion of stocks throughout the region (Brownell, \& Steveley, 1981; Chakalall, \& Cochrane, 1996), causing its inclusion into CITES Appendix II and IUCN's Red List (Stoner, \& Sandt, 1992; Stoner, Glazer, \& Barile, 1996; Acosta, 2006). In Mexico this resource is regulated by the Mexican Official Norm NOM-013-PESC (DOF, $21^{\text {st }}$ of april 1995), which establishes a minimum shell length of $200 \mathrm{~mm}$, temporal fishing ban, fishing only in regulated areas and a fishing quota. The fishing quota is established by yearly evaluation of the resource during which conch density is sampled in designated areas, and estimates of the total adult biomass are obtained based on abundance data. The fishing quota usually represents $50 \%$ of the estimated adult biomass (Basurto Espinosa, Cob, \& Escobedo, 2009). In this context, an adult is defined as an individual $>200 \mathrm{~mm}$ with a lip that cannot be easily broken by hand (NOM-013-PESC, in DOF, $21^{\text {st }}$ of April 1995), which is a very subjective classification. Conchs reach sexual maturity when they are about 3.2years old (Appeldoorn, 1988). The characteristic flared lip of the conch can be used as an indicator of maturity. Appeldoorn (1994), based on his findings argued for the implementation of a minimum size limit of $5 \mathrm{~mm}$ shell lipthickness. Aldana-Aranda and Frenkiel (2007), based on histological observations, determined gonad activity throughout the whole year in conch with a lip $>5 \mathrm{~mm}$ and concluded that only a lip thickness $>5 \mathrm{~mm}$ appears to be a viable maturity criteria and recommended a minimum catch size based on lip thickness of $>7 \mathrm{~mm}$. Ávila-Poveda and Baqueiro-Cárdenas (2006) determined that conch maturity occurs at $13 \mathrm{~mm}$ LT in San Andrés, Columbia, and a more recent study by Stoner, Mueller, BrownPeterson, Davis, and Booker (2012a) suggests that maturity does not occur until females have reached a minimum lip thickness (LT) of $12 \mathrm{~mm}$, suggesting that sustainable management of the conch will require a minimum LT of $15 \mathrm{~mm}$ for harvest.

The queen conch is probably one of the most studied invertebrates. Stoner (1997) reported the existence of about 230 scientific publications on $S$. gigas, many of which deal with population structure (e.g. Stoner, \& Sandt, 1992; Stoner, \& Ray, 1993; De JesúsNavarrete, \& Valencia-Beltrán, 2003), density or abundance (e.g. Berg, \& Glazer, 1991; De Jesús-Navarrete, González, Oliva, Pelayo, \& Medina, 1992; Stoner, \& Ray, 1993; Friedlander, Appeldoorn, \& Beets, 1994; Stoner \& Schwarte, 1994; Ríos-Lara et al., 1998; PérezPérez, \& Aldana-Aranda, 1998; Pérez-Pérez, \& Aldana-Aranda, 2000; Pérez-Pérez, \& AldanaAranda, 2003; Phillips, Bissada-Gooding, \& Oxenford, 2010), and other aspects of population ecology. Nevertheless, none of these works apply basic tools for the evaluation of population stability, such as the intrinsic population growth rate, also known as "Malthusian parameter" or "innate capacity for increase", which can be very easily determined and represents a powerful tool that demonstrates very clearly if a population is stable, growing or in decline (Birch, 1948).

The aims of this study were to estimate the population growth rate $(r)$ by simple linear methods and to simulate the impact of a $50 \%$ adult extraction on the population dynamic and density, defining as adult biomass (1) individuals with a minimum shell length of $200 \mathrm{~mm}$, as suggested by Mexican regulations 
(NOM-013-PESC; DOF, $21^{\text {st }}$ of april 1995); (2) individuals with a lip $\geq 5 \mathrm{~mm}$, as suggested by Appeldoorn (1994) and Aldana \& Frenkiel (2007); (3) individuals with a lip $\geq 15 \mathrm{~mm}$, as proposed by Stoner et al. (2012a), taking as an example the Xel-Ha population, which has been actively protected since 1995, with the finality of presenting a quick and simple tool for easy population evaluation and to demonstrate how minimum catch size affects the population dynamic. The results presented may be used to guide decisions related with fishery management and give an overview on sustainability of harvest efforts.

\section{MATERIALS AND METHODS}

Study site: Xel-Ha is located in the state of Quintana Roo, on the East coast of the Yucatan Peninsula $\left(20^{\circ} 19^{\prime} 15^{\prime \prime} \mathrm{N}-87^{\circ} 21^{\prime} 41^{\prime \prime} \mathrm{W}\right.$ and $\left.20^{\circ} 18^{\prime} 50^{\prime \prime} \mathrm{N}-87^{\circ} 21^{\prime} 15^{\prime \prime} \mathrm{W}\right)$. The area is characterized by influx of fresh water through underground rivers due to karstic conditions in the area. Xel-Ha is a highly stratified coastal lagoon that consists of a mix of fresh groundwater with seawater. The inlet is connected to the Caribbean Sea by a $100 \mathrm{~m}$ wide channel and has a total surface of 14 ha, with a central area and three side branches: Bocana, North Arm and South Arm. Its depth ranges from 0.5-4.0m.

Sampling method: Between January 2005 and January 2008 a total of 23 surveys were carried out, covering a sample area of $3.9 \mathrm{ha}$, distributed throughout three sample sites. Sampling efforts were resumed between April 2009 and September 2011 and an additional 13 surveys were conducted, sampling a total area of 4.5ha, distributed throughout four sample sites. The number of surveys carried out varied among years: in 2005 samples were taken monthly, while between 2006 and 2011 surveys were carried out every two months. All organisms were collected in free-dive by three divers, during three hours at each site. We used mark-recapture method (Krebs, 1999), marking all individuals with a plastic Dymo ${ }^{\circledR}$ tag, bearing a consecutive number, which was fixed to the spire of the conch with a plastic cable binder. A total of 1665 could be tagged in the period from 2005-2008, while 6627 conches were marked between 2009 and 2011. We determined shell length (SL) and lip thickness (LT) for each individual, using a precision caliper, accurate to $\pm 1 \mathrm{~mm}$. All animals were released at the same location they were found. For the purpose of this work we only used the abundance and morphometric data obtained.

A scatter plot was elaborated to show the relationship between lip thickness and shell length during the development of the conch. Basic descriptive statistical parameters were calculated, using the program INFOSTAT/S.

In order to eliminate effects of sample area expansion on the results, abundance was determined for each sampled month and then converted to density per hectare (ind./ha) by dividing the average number of animals observed $(N)$ by the total area sampled (e.g. $N / 3.9$ for 2005-2008 and N/4.9 for 2009-2011). We calculated average density and its standard deviation for each sampled year. The population growth parameter $r$ was determined by calculating the slope between two data points, using the formula $r=(\Delta y / \Delta x)=N_{t+1}-N_{t} / t$ (Gotelli, 1959), where $t$ was 1year $=365$ days.

With the objective of determining the population structure, we used the shell length (SL) and lip thickness (LT) data. Beforehand a correlation was carried out to test if adult abundance was related to the magnitude of recruitment observed in the following year. Since there was no correlation, and in order to simplify the model, age was not taken into account. Three different criteria were applied to classify an adult: (1) an individual with a $\mathrm{SL} \geq 200 \mathrm{~mm}$, as stated in the Mexican Official Norm NOM-013-PESC; (2) an individual with a LT $\geq 5 \mathrm{~mm}$, as defined by Appeldoorn (1988) and Aldana-Aranda \& Frenkiel (2007); (3) an individual with a $\mathrm{LT} \geq 15 \mathrm{~mm}$, as recently proposed by Stoner et al. (2012a). According to these three classifications, mean annual adult abundances and mean relative adult abundances $(\%)$ were calculated. Harvest $(H)$ was 
defined as $50 \%$ adult abundance. Finally, we subtracted $H$ from the population $\left(N_{t}-H\right)$ and then multiplied the resulting number by the beforehand calculated population growth $\left(N_{t+1}\right)$ $N_{t}$ ) to estimate the size of the simulated population for the following interval $\left(\left(N_{t}-H\right) *\left(N_{t+1} /\right.\right.$ $\left.\left.N_{t}\right)=N_{t+1}-H\right)$, simulating a regulated fishing impact. This was repeated for each scenario to demonstrate the impact of the minimum fishing size on the population density.

\section{RESULTS}

Figure 1 shows the number of conch with and without formed lip in different size classes. Almost 17\% (2236 individuals) of the conch without lip were larger than $200 \mathrm{~mm}$ and could be as large as $260-270 \mathrm{~mm}$. S. gigas with a formed lip started to appear in the size class of 150-160mm (Fig. 1).

Figure 2 shows the relationship between lip thickness and shell length. Between 2005 and 2011 a total of 6080 measurements could be obtained. The smallest conch with a formed lip had a shell length of $159 \mathrm{~mm}$ and the largest one a length of $270 \mathrm{~mm}$. More than $20 \%$ of the analyzed conch had a greater LT than $15 \mathrm{~mm}$ and the thickest lip recorded was $54 \mathrm{~mm}$.

The average shell length for conch with formed lip was $209.39 \pm 14.18 \mathrm{~mm}$ and the median $210 \mathrm{~mm}$, half of the sampled conch (50\%-quartile Q1-3) with lip ranged 200$219 \mathrm{~mm}$ length. The total size range of all animals captured in Xel-Ha was 45-270mm.

Figure 3 shows the queen conch's average population densities (and standard deviations) for the total population and for adults, using three different classification criteria, as well as population growth rates $(r)$. Average population densities ranged between a minimum of 46.3ind./ha, observed in 2007, and a maximum of 286.8ind./ha in 2010. Throughout 2005 to 2008 , the population density was more or less constant with values between $46.3 \mathrm{ind}$./ha and $60.1 \mathrm{ind}$./ha, and population growth was negative between 2006 and 2007. However, between 2008 and 2010, the population increased sixfold in density, reaching 286.8ind./ha by 2010 . From 2010 to 2011, the population declined again, but still maintaining a 5-fold higher density value in comparison with the initially stable population of 2005-2008. Growth parameter $r$

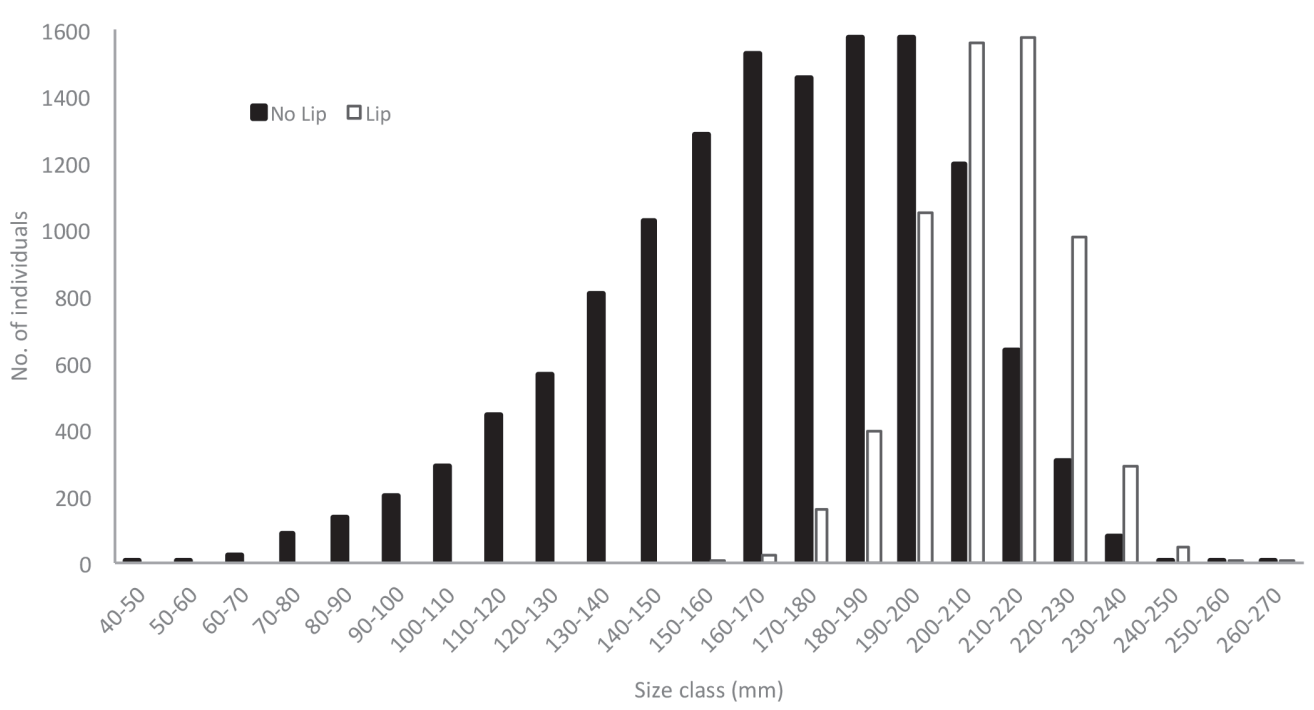

Fig. 1. Absolute frequency of the queen conch Strombus gigas, in the Xel-Ha Inlet, Quintana Roo, Mexico, per size class (shell length $\mathrm{mm}$ ) of animals without a formed lip (no lip) and formed lip. 


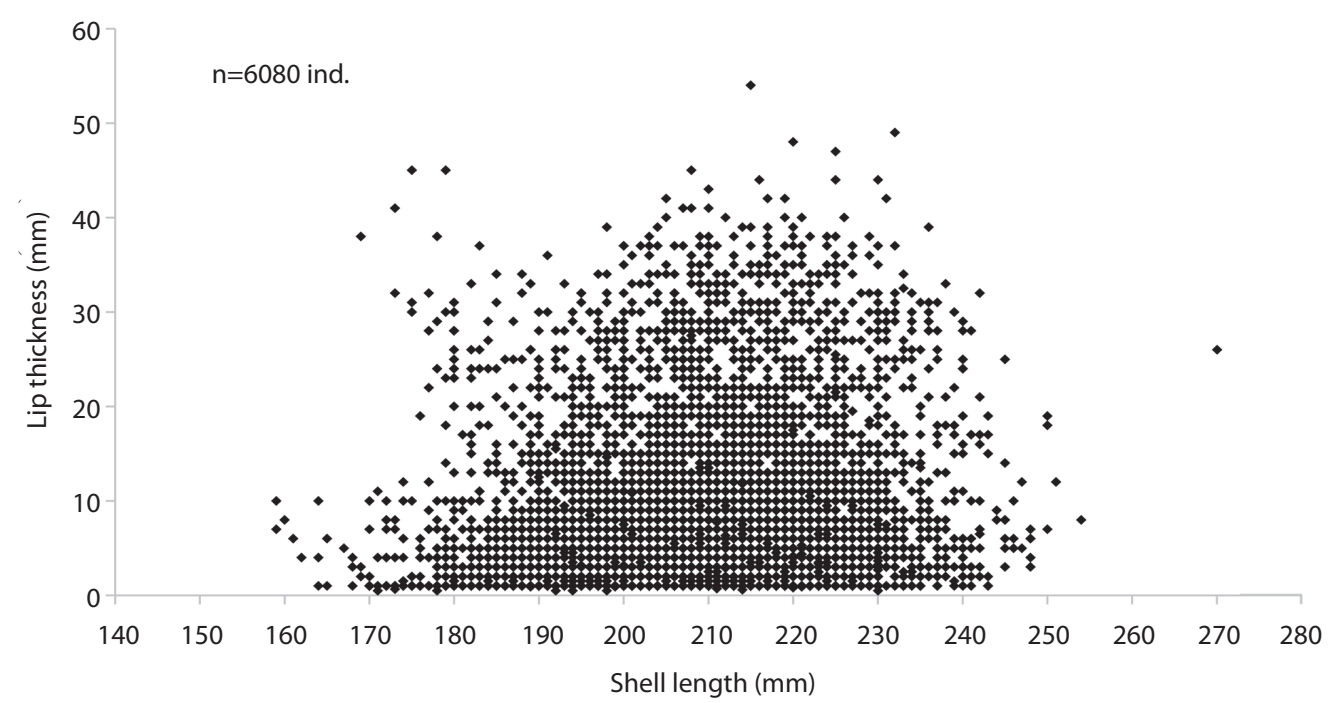

Fig. 2. Relationship between shell length $(\mathrm{mm})$ and lip thickness $(\mathrm{mm})$ of the queen conch Strombus gigas, in the Xel-Ha Inlet, Quintana Roo, Mexico.

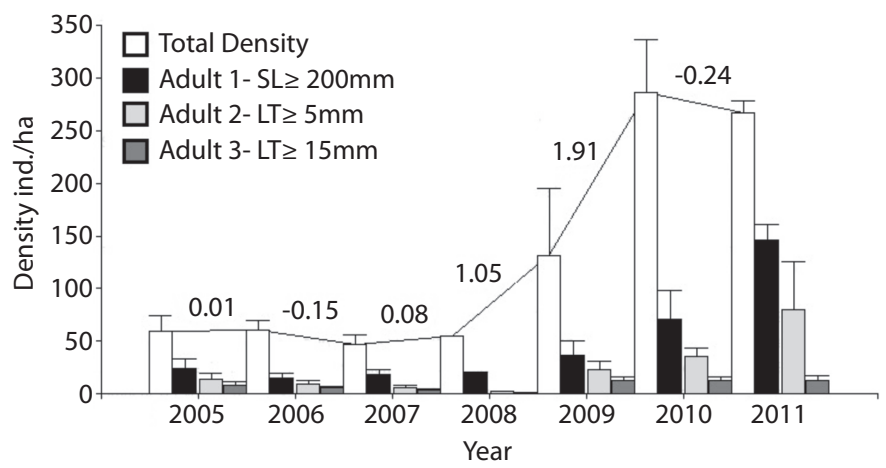

Fig. 3. Total yearly average density (white) per hectare (ind./ha) and yearly average adult densities (ind./ha), of the queen conch Strombus gigas in the Xel-Ha Inlet, Quintana Roo, Mexico; black, conch with $\mathrm{SL} \geq 200 \mathrm{~mm}$; light grey, conch with $\mathrm{LT} \geq 5 \mathrm{~mm}$; dark grey, conch with LT $\geq 15 \mathrm{~mm}$. Connecting lines show population growth rate $r\left(\mathrm{~N}_{\mathrm{t}+1-} \mathrm{N}_{\mathrm{t}} / \mathrm{t}\right)$.

indicates a positive population growth for most of the sampled years, with exception of 20062007 and 2010-2011.

Adult density showed a similar trend as the total population, decreasing gradually between 2005 and 2008, and then increased, almost in an exponential manner, until 2011. The relative adult abundance (\%) (Table 1) and densities (Fig. 3) may vary greatly, depending on how an adult is classified. When classifying an adult as an individual with $\mathrm{SL} \geq 200 \mathrm{~mm}$ (Adult 1), then the population was composed of $26.2-54.8 \%$ of adults, while with the second classification criteria (conch with formed lip $\geq 5 \mathrm{~mm}$, e.g. Adult 2), $4.7-29.8 \%$ of the individuals were counted as adults. Finally, when we classified an adult as an individual with a formed lip $\geq 15 \mathrm{~mm}$ (Adult 3 ), the population was only composed of $2.8-12.7 \%$ adult individuals (Table 1 ).

Simulated fishing impact was greatest when conch with a $S L \geq 200 \mathrm{~mm}$ were extracted, causing the population to reduce to one third 
TABLE 1

Relative queen conch Strombus gigas adult abundance using different classification criteria

\begin{tabular}{cccc} 
Year & $\begin{array}{c}\text { Adult (1) } \\
\%\end{array}$ & $\begin{array}{c}\text { Adult (2) } \\
\%\end{array}$ & $\begin{array}{c}\text { Adult (3) } \\
\%\end{array}$ \\
\hline 2005 & 39.5 & 22.6 & 12.7 \\
2006 & 26.2 & 15.8 & 9.9 \\
2007 & 39.4 & 12.8 & 7.8 \\
2008 & 38.4 & 4.7 & 2.8 \\
2009 & 27.3 & 17.0 & 9.3 \\
2010 & 24.7 & 12.2 & 4.3 \\
2011 & 54.8 & 29.8 & 4.7 \\
\hline
\end{tabular}

(1) individuals with a $S L \geq 200 \mathrm{~mm}$.

(2) individuals with a $\mathrm{LT} \geq 5 \mathrm{~mm}$.

(3) individuals with a $\mathrm{LT} \geq 15 \mathrm{~mm}$.

of its original size by 2010 (Fig. 4). The lowest impact was obtained when simulating the extraction of individuals with a formed lip $\geq 15 \mathrm{~mm}$. Population dynamics maintained a similar trend in comparison to the original population, although in 2010, population reduction with this measurement compromised almost one third of the entire population. The $\geq 5 \mathrm{~mm}$ harvest criteria caused higher impact than the $\geq 15 \mathrm{~mm}$ conch extraction, but maintained similar trends and values, with a higher yield.

\section{DISCUSSION}

Shell length was highly variable at the point of lip formation. The observed mean and median were higher than the minimum fishing size suggested by Mexican authorities, so it can be assumed that many of the conch that are being legally fished are in fact still immature. Also, the SL $\geq 200 \mathrm{~mm}$ extraction policy had the highest negative impact on the density of the simulated population, given that in some years more than half of the population fell under this criteria, which means that more than one quarter of the population could be legally extracted, a practice that cannot be considered sustainable under natural conditions. Cala, Jesús de Navarrete, Ocaña, and Oliva Rivera (2013) expressed similar concerns, pointing out that about $42 \%$ of the sampled population in Banco Chinchorro, one of Mexico's most important commercial conch fishery grounds, are vulnerable to legal fishing when applying the official minimum size requirement. Density decline alone may have several severe ecological implications, potentially disrupting population viability, including Allee effect (Stoner, \& RayCulp, 2000), reduced spawning and reproductive activity (Stoner, Davis, \& Brooker, 2012b; De Jesús-Navarrete, \& Valencia-Hernández,

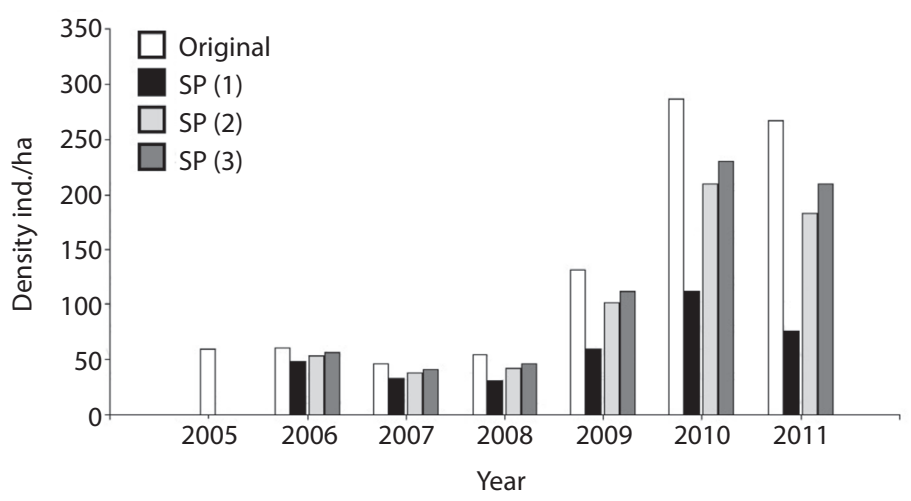

Fig. 4. Original population densities (white) of the queen conch Strombus gigas in the Xel-Ha inlet, Quintana Roo, Mexico and populations after simulated $50 \%$ adult extraction: SP (1) simulated population after $50 \%$ extraction of individuals with a SL $\geq 200 \mathrm{~mm}$ (black); SP (2) simulated population after 50\% extraction of individuals with a $\mathrm{LT} \geq 5 \mathrm{~mm}$ (light grey); and SP (3) simulated population after $50 \%$ extraction of individuals with a $\mathrm{LT} \geq 15 \mathrm{~mm}$ (dark grey). 
2013), as well as increased juvenile mortality (Stoner, 1989; Ray \& Stoner, 1994). Indeed, in Mexico, commercial conch extraction sites had to be temporarily closed due to extreme population declines and low recruitment after applying the above mentioned regulation (Basurto et al., 2009).

Furthermore, selective fishing pressure based on size may lead to the appearance of small adult individuals, as observed in Turks and Caicos Islands (Clerveaux, Danylchuk, \& Clerveaux, 2005) and Berry Island, Bahamas (Stoner et al., 2012b). Fish stocks experiencing high fishing mortality show a tendency to mature earlier and at a smaller size (Eikeset, Richter, Dunlop, Dieckmann, \& Stenseth, 2013), which may also reduce fecundity (Marshall, Needle, Yaragina, Ajiad, \& Gusev, 2004). Large queen conch have higher reproductive potential than smaller individuals (Stoner et al., 2012a), so it can be concluded that fishing regulations based on shell length may also decrease the reproductive potential of a population through size selection.

Using the minimum lip thickness suggested by Appeldoorn (1988) and AldanaAranda and Frenkiel (2007) the impact on the population density was much less severe in the numerical scenario, given that the fraction of the population considered as mature was much smaller than when using the classification criteria based on SL, which was also the case for the populations simulated with Stoner et al. (2012a) adult criteria. However, biologically there may be a significant impact, given that animals may not yet be mature presenting a LT of $5 \mathrm{~mm}$, which may lead to deterioration of reproductive success and disrupt the connectivity between populations (Stoner et al., 1996). Conch behavior also suggests that conch mature at larger SLs than suggested by the Mexican Norm, and greater LTs. Prior to this study an investigation on movement patterns of the queen conch in Xel-Ha was carried out. It could be demonstrated that conch move from the interior of the inlet towards the mouth as they grow older (Peel, \& Aldana-Aranda, 2012). The mouth of the inlet (Bocana) has been characterized as a reproductive site, observing mating and egg laying (Aldana-Aranda et al., 2005; SánchezCrespo, \& Aldana-Aranda, 2012), as well as stage I larvae in the water column (ChávezVillegas, 2011). Movements and redistribution were strongly related to size, the individuals which moved towards the mouth had mean LTs between $11 \mathrm{~mm}$ and $18 \mathrm{~mm}$ and mean SLs between $204 \mathrm{~mm}$ and $212 \mathrm{~mm}$. Also, movements were more frequent during summer, which strongly suggested that this dispersal behavior could be related to the first reproduction (Peel, \& Aldana-Aranda, 2012), and indicates that it occurs at bigger sizes than $5 \mathrm{~mm}$ LT.

Taking into account the present study, the ethology of the species (Peel, \& AldanaAranda, 2012), the drastic decline of Mexican populations (Basurto et al., 2009), eminent evidence for decreasing reproductive activity due to population decline (De Jesús-Navarrete, \& Valencia-Hernández, 2013), and the recent results obtained by Stoner et al. (2012a), it is clear that there is a strong need to revise and adjust the minimum catch size of the queen conch in order to maintain sustainability of populations, given that the actual legislation does not protect the reproductive stages, leads to unsustainable fishery yields and size selection. We therefore suggest basing the minimum catch size on lip thickness instead of shell length, and recommend a minimum legal fishing size of $15 \mathrm{~mm} \mathrm{LT}$.

\section{ACKNOWLEDGMENTS}

We thank Dalila Aldana Aranda, CINVESTAV-Merida and CONACYT for the financial support through the project, INNOVATEC-CONACYT-183724, CINVESTAVIPN and student scholarship 374674/243375, allowing the generation of the published data during my MSc in Marine Biology obtained at CINVESTAV-Merida, Mexico. Special thanks go to Xel-Ha's Executive Director Elizabeth Lugo and the department for Sustainable Management for the unconditional support and unlimited access during our work. 


\section{RESUMEN}

Impacto de la talla mínima de captura en la viabilidad de la población de Strombus gigas (Mesogastropoda: Strombidae) en Quintana Roo, Mexico. El caracol rosa Strombus gigas representa una de las especies de mayor importancia pesquera en el Caribe, pero la creciente presión pesquera ha llevado al deterioro de las poblaciones en toda la región, llevando a la inclusión de esta especie en el apéndice II de CITES y la lista roja de UICN. En México, el caracol rosa se maneja con una talla mínima de pesca de $200 \mathrm{~mm}$ longitud de heliconcha y una cuota pesquera que generalmente representa el $50 \%$ de la biomasa adulta. Este estudio tuvo como objetivos determinar la tasa intrínseca de crecimiento poblacional del caracol rosa en Xel-Ha, Quintana Roo, México, y evaluar el efecto de un esfuerzo pesquero regulado, simulando la extracción del $50 \%$ de la biomasa adulta. Utilizamos tres diferentes criterios de talla mínima para la pesca, para evaluar el efecto de ésta sobre la densidad de la población y discutimos las implicaciones bilógicas asociadas. Los datos demográficos se obtuvieron mediante un muestreo de marcaje-recaptura, recolectando todos los animales presentes, durante tres horas, con tres buzos, en cuatro sitios diferentes de la caleta. En 2005 los muestreos fueron mensuales, y de 2006 a 2011 bimensuales, marcándose un total de 8292 caracoles. Se obtuvo la longitud de heliconcha y grosor de labio de cada individuo. La talla media de caracoles con labio formado fue de $209.39 \pm 14.18 \mathrm{~mm}$ y la mediana de $210 \mathrm{~mm}$. La mitad de los caracoles con un labio formado presentaban tallas de $200 \mathrm{~mm}$ a $219 \mathrm{~mm}$ longitud de heliconcha. Suponiendo que la presencia del labio es un indicador de madurez sexual, se puede concluir que muchos animales alcanzan la madurez sexual a tallas mayores de $200 \mathrm{~mm}$ longitud de heliconcha y deberían ser considerados inmaduros. La estimación de la abundancia relativa y densidad de adultos varía ampliamente según el criterio de clasificación utilizado. Cuando se aplicó una talla mínima de $200 \mathrm{~mm}$ longitud, el $26.2 \%$ a $54.8 \%$ de la población calificó como adulta, correspondiendo a un impacto pesquero simulado de casi un tercio de la población. El impacto fue menor simulando la extracción de adultos, utilizando un criterio de clasificación basado en grosor de labio. Se concluyó que la mejor estrategia de manejo para $S$. gigas es una talla mínima basada en el grosor de labio, ya que esta medida reduce el impacto sobre la densidad poblacional, y por el otro lado disminuye la presión selectiva sobre la talla, lo cual conduce a la aparición de individuos pequeños con fecundidad inferior. Más allá, basado en la biología reproductiva y los resultados de las simulaciones, recomendamos un grosor de labio mínimo de $\geq 15 \mathrm{~mm}$ para la pesca, ya que esta medida asegura la protección de las etapas reproductivas y reduce el riesgo de sobrepesca, el cual llevaría a reducciones no viables de la densidad poblacional.

Palabras clave: manejo pesquero, sustentabilidad pesquera, madurez sexual.

\section{REFERENCES}

Abott, R. T. (1974). American seashells; the marine mollus$\mathrm{ka}$ of the atlantic and pacific coasts of north america. New York: Van Nostrand Reinhold Company.

Acosta, A. C. (2006). Impending trade suspensions of Caribbean queen conch under cites: A case study on fishery impacts and potential for stock recovery. Fisheries, 31, 601-606.

Alcolado, P. M. (1976). Crecimiento, variaciones morfológicas de la concha y algunos datos biológicos del cobo Strombus gigas L. (Mollusca, Mesogastropoda). Academia de Ciencias de Cuba Serie de Oceanología, 34, 1-36.

Aldana-Aranda, D., Sánchez-Crespo, M., Reynaga Alvarez, P., Patiño-Suárez, V., George-Zamora, A., \& Baqueiro-Cárdenas, E. R. (2005). Crecimiento y temporada reproductiva del caracol rosa Strombus gigas en el parque Xel-Há, México. Proceedings of the Gulf and Caribbean Fishery Institute, 56, 741-754.

Aldana-Aranda, D. \& Frenkiel, L. (2007). Lip thickness of Strombus gigas, Mollusca Gastropoda versus maturity: a management measure. Proceedings of the Gulf and Caribbean Fishery Institute, 58, 431-442.

Appeldoorn, R. S. (1988). Age determination, growth, mortality and age of first reproduction in adult queen conch, Strombus gigas L., off Puerto Rico. Fishery Research, 6, 363-378.

Appeldoorn, R. S. (1994). Spatial variability in the morphology of queen conch and its implication for management regulations. In R. S. Appeldoorn \& B. Rodriguez (Eds.), Queen conch biology, fisheries and management (pp. 145-158). Caracas: Fundación Científica Los Roques.

Ávila-Poveda, O. H. \& Baqueiro-Cárdenas, E. R. (2006). Size at sexual maturity in the queen conch Strombus gigas from Colombia. Boletín de Investigación Marina y Costera, 35, 223-233.

Baqueiro-Cárdenas, E. R. \& Aldana-Aranda, D. (2010). Histories of success for the conservation of populations of queen conch (Strombus gigas). Proceedings of the Gulf and Caribbean Fishery Institute, 62, 306-312.

Basurto, M., Espinosa, J. M., Cob, E., \& Escobedo, G. (2009). Dictámen Técnico: Estimación de biomasa explotable de Strombus gigas en los bancos abiertos a la pesca en Quintana Roo, México: Banco Chinchorro y Banco de Cozumel. Temporada de Captura 2009-2010.

Berg, C. J. \& Glazer, R. A. (1991). Current research on queen conch (Strombus gigas) in Florida waters. Proceedings of the Gulf and Caribbean Fishery Institute, 40, 303-306. 
Birch, L. C. (1948). The intrinsic rate of natural increase of an insect population. Journal of Animal Ecology, 17, 15-26.

Brownell, W. N. \& Stevely, J. M. (1981). The biology, fisheries and management of the queen conch Strombus gigas. Marine Fishery Review, US Department of Commerce, 43(7), 1-12.

Cala, Y. R., Jesús de Navarrete, A., Ocaña, F. A., \& Oliva Rivera, J. (2013). Densidad, estructura de tallas y actividad reproductive del caracol rosado Eustrombus gigas (Mesogastropoda: Strombidae) en Banco Chinchorro, México. Revista de Biología Tropical, 61(4), 1657-1669.

Chakalall, B. \& Cochrane, K. L. (1996). The queen conch fisheries in the Caribbean - An approach to responsible fishery management. In J. M. Posada \& G. Garcia-Moliner (Eds.), Proceedings of the First International Queen conch Conference, San Juan, Puerto Rico, 29-31 July 1996 (pp. 60-76). San Juan: Caribbean Fisheries Management Council.

Chávez-Villegas, J. F. (2011). Abundancia espacio-temporal de larvas de Strombus gigas (Linnaeus, 1758) en el sistema arrecifal mesoamericano (Master's thesis). CINVESTAV-IPN, Mérida.

Clerveaux, W., Danylchuk, A. J., \& Clerveaux, V. (2005). Variation in queen conch shell morphology: management implications in the Turks and Caicos Islands, BWI. Procedings of the Gulf Caribean Fishery Institute, 56, 715-724.

Davis, M., Mitchell, B. A., \& Brown, J. L. (1984). Breeding behavior of the queen conch $S$. gigas held in natural and enclosed habitat. Journal of Shellfish Research, 4(1), 17-21.

De Jesús-Navarrete, A., González, E., Oliva, J., Pelayo, A., \& Medina, G. (1992). Advances over some ecological aspects of queen conch Strombus gigas, L. in the southern Quintana Roo, Mexico. Proceedings of the Gulf and Caribbean Fishery Institute, 45, 18-24.

De Jesús-Navarrete, A. \& Valencia-Beltrán, V. (2003). Abundance of Strombus gigas zero-year class juveniles at Banco Chinchorro Biosphere Reserve, Quintana Roo, Mexico. Bulletin of Marine Science, 73, 232-240.

De Jesús-Navarrete, A., \& Valencia-Hernández, A. (2013). Declining densities and reproductive activities of the queen conch Strombus gigas (Mesogastropoda: Strombidae) in Banco Chinchorro, eastern Caribbean, Mexico. Journal of Tropical Biology, 61(4), 1671-1679.

Eikeset, A. M., Richter, A. Dunlop, E. S., Dieckmann, U., \& Stenseth, N. C. (2013). Economic repercussions of fisheries-induced evolution. PNAS, 110(30), 12259-12264.
Friedlander, A., Appeldoorn, R. S., \& Beets, J. (1994). Spatial and temporal variations in stock abundance of queen conch, Strombus gigas, in the U.S. Virgin Islands. In R. S. Appeldoorn \& B. Rodriguez (Eds.), Queen conch biology, fisheries and management (pp. 51-60). Caracas: Fundación Científica Los Roques.

Gotelli, N. J. (1959). A primer of ecological statistics. Sunderland, Massachusetts: Sinauer Associates, Inc.

Krebs, C. J. (1999). Ecological Methodology, 2nd ed. Vancouver: Addison-Wesley Educational Publishers, Inc.

Marshall, C. T., Needle, C. L., Yaragina, N. A., Ajiad, A. M., \& Gusev, E. (2004) Deriving condition indices from standard fisheries databases and evaluating their sensitivity to variation in stored energy reserves. Canadian Journal of Fishery and Aquatic Science, 61(10), 1900-1917.

Peel, J. R. (2012). Dinámica poblacional y utilización ontogénica del hábitat por el Caracol rosa (Strombus gigas), en el parque Xel-Há, Quintana Roo, México (Master's thesis). Centro de Investigación y de Estudios Avanzados del Instituto Politécnico Nacional (CINVESTAV-IPN), Mérida.

Peel, J. R. \& Aldana-Aranda, D. (2012). Size related distribution and mobility of the queen conch Strombus gigas in the Xel-Há Park, Mexican Caribbean. Book of Abstracts of the Proceedings of the Gulf and Caribbean Fishery Institute, 65, 154.

Pérez-Pérez, M. \& Aldana-Aranda, D. (1998). Análisis preliminar de la densidad del caracol rosado (Strombus gigas) en el arrecife Alacranes Yucatán, México. Proceedings of the Gulf and Caribbean Fishery Institute, 50, 49-65.

Pérez-Pérez, M. \& Aldana-Aranda, D. (2000). Distribución, abundancia, densidad y morfometría de Strombus gigas (Mesogastropoda: Strombidae) en el Arrecife Alacranes Yucatán, México. Revista de Biología Tropical, 48, 51-57.

Pérez-Pérez, M. \& Aldana-Aranda, D. (2003). Actividad de Strombus gigas (Mesogastropoda: Strombidae) en diferentes hábitats del arrecife Alacranes, Yucatán. Revista de Biología Tropical, 51, 119-126.

Phillips, M., Bissada-Gooding, C., \& Oxenford, H. A. (2010). Preliminary investigation of the movements, density, and growth of juvenile queen conch in a nursery area in Barbados. Proceedings of the Gulf and Caribbean Fishery Institute, 63, 427-434.

Randall, J. E. (1964). Contribution to the biology of the queen conch Strombus gigas. Bulletin of Marine Science, 14, 246-295.

Ray, M. \& Stoner, A. W. (1994). Experimental analysis of growth and survivorship in a marine gastropod aggregation: balancing growth with safety in numbers. Marine Ecology Progress Serie, 105, 47-59. 
Ríos-Lara, G. V., Cervera-Cervera, K., Espinoza-Méndez, J. C., Pérez-Pérez, M., Zetina-Moguel, C., \& Chable Ek, F. (1998). Estimación de las densidades de langosta espinosa (Panulirus argus) y caracol rosa (Strombus gigas) en el área central del Arrecife Alacranes, Yucatán, México. Proceedings of the Gulf and Caribbean Fishery Institute, 50, 104-127.

Sánchez-Crespo, M. \& Aldana-Aranda, D. (2012). Caracterización del periodo reproductivo y desove del caracol rosa Strombus gigas en el parque Xel-Há, Quintana Roo, México. Book of Abstracts of the Proceedings of the Gulf and Caribbean Fishery Institute, $65,154$.

Stoner, A. W. (1989). Density-dependent growth and grazing effects of juvenile queen conch Strombus gigas L. in a tropical seagrass meadow. Journal of Experimental Marine Biology and Ecology, 130(2), 119-133.

Stoner, A. W. (1997). The status of queen conch Strombus gigas research in the Caribbean. Marine Fishery Research, 59(3), 14-22.

Stoner, A. W., Glazer, R. A., \& Barile, P. J. (1996). Larval supply to queen conch nurseries: Relationships with recruitment process and population size in Florida and the Bahamas. Journal of Shellfish Research, 15(2), 407-420.

Stoner, A. W. \& Ray-Culp, M. (2000). Evidence for Allee effects in an over-harvested marine gastropod: density-dependent mating and egg production. Marine Ecology Progress Series, 202, 297-302.

Stoner, A. W., Mueller, K. W., Brown-Peterson, N. J., Davis, M. H., \& Booker, C. J. (2012a). Maturation and age in queen conch (Strombus gigas): Urgent need for changes in harvest criteria. Fishery Research, 131-133, 76-84.

Stoner, A. W., Davis, M. H., \& Brooker, C. J. (2012b). Negative consequences of Allee effect are compounded by fishing pressure: comparison of queen conch reproduction in fishing grounds and marine protected area. Bulletin of Marine Science, 88(1), 89-104.

Stoner, A.W. \& Ray, M. (1993). Aggregation dynamics in juvenile queen conch (Strombus gigas): population structure, mortality, growth and migration. Marine Biology, 116, 571-582.

Stoner, A. W., \& Sandt, V. J. (1992). Population structure, seasonal movements and feeding of queen conch, Strombus gigas, in deep water habitats of the Bahamas. Bulletin of Marine Science, 51, 287-300.

Stoner, A. W. \& Schwarte, K. C. (1994). Queen conch, Strombus gigas, reproductive stocks in the central Bahamas: distribution and probable sources. Fishery Bulletin, 92, 171-179.

Thiele, S. (2001). Queen conch fisheries and their management in the Caribbean. (Technical Report to the CITES Secretariat in Completion of Contract A 2000/01). Traffic Europe. 